\title{
Patient Experiences In Internal And Surgical Ward At State Hospital Labuang Baji Makassar
}

\author{
Nur Arifah \\ Department of Hospital Management \\ Faculty of Puclict Health \\ Hasanuddin University \\ Makassar, Indonesia \\ nur.arifah@gmail.com
}

\author{
Fridawaty Rivai \\ Department of Hospital Management \\ Faculty of Puclict Health \\ Hasanuddin University \\ Makassar, Indonesia \\ fridarivai@yahoo.com
}

\author{
A. Zulfaidah Putri Delima \\ Department of Hospital Management \\ Faculty of Puclict Health \\ Hasanuddin University \\ Makassar, Indonesia
}

\begin{abstract}
Abstract-People use the term patients experience and patient's satisfaction, alternately. As a matter fact, these two terms are different specifically in terms of measurement's concept. Patient satisfaction survey usually consist of questions that do not really measure the exact treatment experience. Satisfaction is considered to be failed in affecting the improvement of quality of care. This can only be measured by patients' experiences data. The aim of this study was to describe the patients' experiences in State Hospital Labuang Baji Makassar. Patients in State Hospital Labuang Baji Makassar. The population number was 3.315. Sample were gained using proportional stratified random sampling and there were 93 respondents chosen.

It is found that; 1) 100 percent respondents experienced a good level of privacy and safety; family involvement in their care; clearness of standard operational procedure; and patients have trusts on the doctors and nurses. However, there were 34.4 percent respondents disagree on the cleanliness in restrooms. 30 percent of respondents were unhappy with the food and drinks provided. 72.9 percent respondents stated nurses did not introduce their selves to patients. 38.7 percent respondents stated the hospital environment was bad. Generally, respondents have good experiences in the hospital unless the cleanliness of the restrooms, taste of food and drinks provided lack of introduction from nurses and hospital environment. It is suggested to the hospital management to make improvement on the cleanliness of restrooms, food and drink taste and the hospital environment and to conduct patient experience survey continuously.
\end{abstract}

Keywords: Patients' experiences, Patients' satisfaction, Quality of care

\section{INTRODUCTION}

The quality of hospital services has two components, namely compliance with predetermined quality standards and fulfillment of patient satisfaction. Hospitals should provide services that focus on patient satisfaction [1]. Improving the quality of health care could start with evaluating the elements that play a role in shaping patient satisfaction. Every person for their health needs needs hospital service, thus it is expected that good service quality can grow and influence patient's decision and trust in order to create patient satisfaction in using the health service [2]. To define patient's satisfaction is to say a patient's feeling and disappointment after comparing it with a performance or result felt with their hope. Patients will feel satisfied if there is a similarity between the expectations and reality of health services received, while dissatisfaction will arise if the outcomes do not meet the patient's expectations [3]. The terms patient satisfaction and patient experience is often used interchangeably, but they are not the same thing in terms of the concept of the value. Satisfaction, on the other hand, is the patient's expectation of the care provided, while in order to assess the patient's experience, one must find out from the patient about the care path provided with the appropriate health care management and how often it occurs [4]

Measuring patient experience is important as it provides opportunities to improve care, improve strategic decision making, fulfilling patient expectations, effectively manage and monitor the performance of health services, and guideline documents for health care organizations. Measuring patient experience can also inform an organization on improving clinical processes and outcomes, resource utilization, and patient safety improvement. Furthermore, the organization also wants its patients to return, recommend to friends and family, and to give a positive impression of their health care experience [5].

Based on secondary data from Labuang Baji' Hospital Makassar, datas obtained on patient satisfaction in 2014 is by $65.3 \%, 2015$ by $78.5 \%$, and year 2016 by $76.8 \%$. Based on this patient satisfaction data, it can be seen that the percentage of the last three years fluctuated and did not meet the Minimum Service Standard in 2012, which is by $\geq 90 \%$. As of the data on the number of inpatient visits over the last three years, it has also experienced fluctuations. Based on these facts, the purpose of this study is to know the description of patient experience in Internal and Surgical Ward Installation of Labuang Baji' Hospital Makassar.

\section{LITERATURE REVIEW}

Patient experience is a variety of patients' interactions with the healthcare system, including their care from health planning, doctors, nurses and other hospital staff, medical practice and other health facilities. As an integral component from health quality, patient experience cover all aspects in care 
delivery that will be valued by patient when they seek and receive care, such as appointment time, the easiness to access information and an effective communication with the service providers [6]. Patient experience is also defined as whole interactions formed by organizational culture which effect patient perception towards all care centers. This shows that patient experience is strongly related to patient expectations and a primer focus on perception of satisfaction. Focus on patient experience has been developed widely as the competition in health care industry increase and the increase of demand to improve patient loyalty, quality of health outcomes, market, and reputation to reach a stable financial reward [7].

Patient experience ensures the health service provision is responsive to patients' preference, needs and values. The National standard of quality and safety of health services in Australia urged to "consumers' involvement in organizational and strategic process which lead to planning, design and health care evaluation". A routine integration of patient experience data to the health system appraisal and evaluation is one of the first steps towards a patient centered care. Patient experiences data can be used to maintain adaptation and to fix services as well as the process of care in order to meet patient needs. The data is also able to give idea on how far patient centered care has been achieved from patient's individual perspective. The objective of patient experience, which has been explained, will improve the focus on patient experience measurement. There are a variety of reasons why feedback from patients would be considered useful; it may lead to a good understanding on current problems in hospital, to inform continuous improvement of care provided, and to redesign the services, to help health care professionals to reflect their own practices and their teams, supervision on the effect of changes, to facilitate comparison between health services, comparing organization to assess the performance, to inform doctors about the quality of care, to inform patients about the journey of care, to help patients in finding high qualified suppliers [8].

In this study, patient experience was measured from admission to hospital, care and treatment, operation and procedure, hospital staff, hospital and ward environment, leaving hospital, pain management and discharge information. Patient experience measurement goals are to provide information on quality of healthcare and treatment from patient perspective as well as other clients' perspectives who receive hospital services.

\section{METHOD}

\section{A. Participants}

This research is a descriptive study. It was conducted in April-May 2017. The population was internal hospital and surgical patients of State Hospital Labuang Baji Makassar at the time of the study. Sampling was determined by using simple random sampling technique. The number of samples in this study were 93 respondents, divided into 74 internal patients and 19 surgical patients.

\section{B. Procedures}

Data collection was done by interview using questionnaire.

\section{Measures}

The data analysis is univariate. Data is then served in the form of tables long with its narration.

\section{RESULT}

Based on the results of this study, the patient's experience on admission to hospital variables of the highest case category is emergency cases from internal patients ranging up to $70.3 \%$, while $52.6 \%$ of the surgical patients were on the waiting list. The hospital entrance passes through the ER for internal patients is as much as $81.9 \%$, while as much as $52.5 \%$ of surgical patients did not pass the ER. Clear statements on waiting time information, length of waiting time to meet doctor / nurse and information presented about patient condition during their time in the ER is of $50 \%$ for internal patients and $100 \%$ for surgical patients. For ease of explanation, understanding from ER officers is of $80 \%$ for internal patient and $100 \%$ for surgical patient with clear answers. Provisions of privacy and safety in the ER is of $100 \%$ and all patients stated clearly. For patients in the waiting list, about the length of waiting time for hospital admission, most patients said it was not long, the information given before admission to the hospital were plenty. As for when the patient was admitted to the hospital until the hospitalization, $93.2 \%$ of the internal patients stated not long and $100 \%$ for the surgical patients.

Patient's experience on hospital and ward environment in room care hygiene is of $44.1 \%$ in agreement and $34.4 \%$ disagreement for the bathroom. Overall, patients stated disagreement on noise caused by other patients, hospital staffs, and disturbed by patient visitor. At the pleasure of food and drink received is as much as $63.4 \%$ agreement and on receiving assistance in a reasonable time is as much as $100 \%$ agreement. The knowledge of patients on nurses on duty, which states "no", is as much as $40.5 \%$, though it does not affect the health care received. There is always availability of hand-washing soap. On the availability of space for one patient, they stated no and felt happy for $75.7 \%$ of internal patients and $100 \%$ for surgical patients. The entire patient is happy with the visiting hours, and for the adequacy of the visiting hours all patients say yes right with enough time to be with family / friends.

Treatment and treatment variables found that in pain relievers, adequacy of privacy under conditions of care, assistance for washing, eating, dressing and assistance to the bathroom and physical comfort were as much as $79.6 \%$ where all patients agreed. Clear with the involvement of patients and families in decision-making regarding care and treatment, the implementation of adequate physical procedures is $100 \%$. No incidences of adverse conditions from time to time for patients, no problems and events during hospitalization and no removal patient care room as much as $100 \%$. Operational and procedural variables on the provision of surgery and procedure operations is of $100 \%$ for internal patients that stated no and as many as $100 \%$ of surgical patients stated yes. The patient's overall understanding of the treatment procedure, the explanation of treatment implementation, the patient's notice of feeling after the explanation was given, the patient's understanding of the staff response and the post-action understanding stated true were done $100 \%$. 
Based on the results of this study, it is found that the variable of health staffs (hospital staffs) on the doctor's knowledge about the patient's condition and the provision of information about the condition and treatment with the statement agreed is as much as $98.9 \%$. The doctor spoke as if the patient was not there is agreed as much as $87.1 \%$, the doctor listened to the patient when they had questions is $79.6 \%$ agreed, the awareness of the doctor to wash their hands is as much as $41.9 \%$ neutral, and trust towards doctors who treated the patients is as many as $100 \%$ agreed. In the nurses' knowledge on the condition of the patient, the provision of information about the patient's condition, the nurse speaks as if the patient is not there, the nurse listens to the patient when they have questions and trust towards the caring nurse is as much as $96.8 \%$ agreed. For awareness of the nurse to wash their hands, $40.9 \%$ stated neutral. As for the patients' knowledge on the nurses responsible for internal patients is as much as $44.6 \%$ and $78.9 \%$ of surgical patients said no but felt happy if they had known. Availability of nurses who served, $100 \%$ of all patients stated there were always enough nurses. On staff cooperation and staff attention to the essentials, 100\% of all patients stated true. In addition, the patients $100 \%$ always said yes on getting emotional support and compassion during the patient being treated.

\section{DISCUSSION}

Admission to the hospital, seen from the process of patient registration, is the beginning of the entire process of medical record or first service received by a patient upon arrival at the hospital, through this process of registration the patient determined whether they had a good or bad impression of a service from the hospital. Therefore, in this registration system officers should be friendly, courteous, orderly and responsible for the patients to feel cared for and served well [9]. According to the respondents, the admission to hospital assessment is in good category, however respondents at the hospital's emergency room stated that they waited too long to enter the ward room. Waiting time is a sensitive matter, meaning that waiting time could risk a hospital's quality of health services to decrease. Inefficient waiting times can invite patients' dissatisfaction with the health service. Patients will consider it as poor health services if the pain does not reduce quickly, long waiting time, and health workers are not friendly though professional [10].

Hospital and ward environment is an effort to supervise various physical, chemical, and biological factors, which could cause bad influence to health officers, patients, visitors and the community around the hospital. Hospital's environment is an effort and a part which cannot be separated from the health care system in providing the best services and care for patients, such as building hygiene, bathrooms, food service drinks and others [11]. According to respondents, some provided poor assessment on the hospital environment, hospitalization due to hygiene around the hospital, treatment rooms and toilets are still very dirty, and hospital buildings that look worn-out and old. The environmental condition of the wardroom also affects the patient psychologically. Noisy wardrooms, high air temperatures, poor lighting, poor hygiene and tidiness will increase stress for the patients. Wardrooms should generate optimism to assist the patient's healing process [12].

Care and treatment is an effort of nursing service that is an integral part of health services performed by nurses by involving other health teams [13]. According to respondents, the assessment of care and treatment during hospitalization is good, such as the implementation of adequate physical procedures by health personnel, there is always patient and family involvement in decisions about care and treatment that is to be received, as well as the patient's privacy rights are maintained. Hospitals respect the right of the patient, in some situations, patient's family has the right to determine which information relating to care services may be informed to the family or others in certain situations [14]. When staffs provide services to patients, they need to ask the patient's needs and expectations on their privacy in the relation with the care or service. Communication between staff and patients builds trust and open communication that does not need to be documented [15].

Operations and procedures are a standardized instructional tool for completing a certain routine of work process, where standard operating procedures provide the right and best steps based on mutual consensus to carry out various activities and service functions, created by standardized health care facilities profession [16]. According to the respondents, the implementation of the operation and procedures has been good. The staff would explain to the patient what to do about the treatment to be administered, but only the surgical patient got the surgery and the procedure while the internal patient did not. One effort to maintain patient safety is through applying standard operational procedures in every nurse's actions. Patient safety aims to improve service and avoid malpractice charges. These performance standards can simultaneously be used to assess the performance of government agencies, both internally and externally [17].

Hospital staff with improved quality of care for the patients should pay attention to patient care management given by doctors, nurses and other health personnel's who must collaborate, coordinate, and cooperate with each other to provide information and have a common goal of healing the patient. The relationship of nurses and doctors are two professions that have a significant role in providing health services to patients. Collaboration is based on mutual respect and affection. There is no single profession in the hospital, whether doctors or nurses, that stands with interdependence. Everything would work well, the patient could be well managed, the problem could be solved well, when all are able to cooperate [18]. According to the respondents, the assessment of health personnel experience is good, however, there are some doctors / nurses who may have washed their hands but the patients did not know and the patient also did not know the name of the nurse in charge and serving. Communication in establishing intimacy between doctors and nurses is shown with a friendly attitude, said a polite and wellmannered word and greetings. In addition, doctors and nurses must have the techniques or skills, such as looking at the 
patient while talking, maintaining eye contact, showing attentiveness, nodding if the patient is talking about important things or needing feedbacks, open up to questions and suggestions. Through this communication, the relationship of doctors and nurses with patients can be well-established [19]. The description of the patient's experience at internal and surgical wards at Labuang Baji Hospital Makassar is good, although there are still some elements of patient experience that need to be considered, such as for the hospital and ward environments, operations, and procedures. Most respondents stated that the feeling of being too long to enter ward, treatment rooms and toilets are still very dirty due to the lack of janitorial staff, lack of patient knowledge of the nurses on duty, as well as all patients getting the implementation of the health care procedures. Suggestions to the hospital, among others, is that the hospital to further improve the quality of services provided to patients on admission to hospital such as patients not waiting too long in the ER to go into hospitalization, hospital maintenance, attention to cleanliness of the environment, introduction from the nurses to the patients, and notifying them on the operational standards of the procedure applied to the patient being treated.

\section{REFERENCES}

[1] Yudha A. "Gambaran Kepuasan Pasien Pada Pelayanan Rawat Jalan Di RSU Kota Tangerang Selatan Tahun 2013" skripsi, Jakarta: Universitas Islam Negeri Syarif Hidayatullah, 2013.

[2] [2] Santoso. "Analisis Pengaruh Kualitas Pelayanan Terhadap Kepuasan Pasien Rawat Inap Kelas III Pada RS. Roemani Muhammadiyah Semarang" skripsi, Semarang: Universitas Diponegoro, 2012.

[3] [3] Azis A. (2012) "Analisis Tingkat kepuasan Pasien Terhadap Pelayanan Keperawatan Prima di RSUP DR. M. DJAMIL Padang tahun 2012” Jurnal Keperawatan. 2012;1(1):45-40.

[4] [4] Edgman, Levitan. "What Is Patient Experience Journal Agency For Healthcare Research And Quality”. 2013;2(1):16-12.
[5] [5] Gallan AS, LaVela SL. "Evaluation And Measurement Of Patient Experience. Patient Experience Journal". 2014;1(1):13-11.

[6] Edgman \& Levitan. "What Is Patient Experience Journal Agency For Healthcare Research And Quality".Patient Experience Journal. Volume 2. 2013.

[7] Harrison, Walton \& Manias. Patient Experience In Australian Hospital. Australia 2015, pp.7-49

[8] Jason, Niederhauser, V., Marshburn, D. \& Lavela, S. L. "Defining Patient Experience". Patient Experience Journal, Volume 1. 2014

[9] Andriani R, Humairah A, Istiqomah A, Abigail Y, Ayuska D, Nurilasari A, et al. "Sistem Pendaftaran Pasien. Jurnal Kesehatan UGM .2(2):2325. [2009]

[10] [10] Bustani NM, Rattu AJ, Saerang JSM. "Analisis Lama Waktu Tunggu Pelayanan Pasien Rawat Jalan Di Balai Kesehatan Mata Masyarakat Propinsi Sulawesi Utara". Jurnal e-Biomedik (eBm). 3(3):17-15 [2015].

[11] [11] Edvardsson, Watt \& Pearce. Patient Experiences Of Caring And Person-Centredness Are Associated With Perceived Nursing Care Quality. Original Research: Empirical Research- Quantitative. Journal Of Medicine National Health. 1(2);19-17 [2016].

[12] [12] Fauziah A. "Pengaruh Kenyamanan Lingkungan Fisik Ruang Rawat Inap Kelas Iii Terhadap Kepuasan Pasien Di Rsui Kustati Surakarta" skripsi. Surakarta: Universitas Sebelas Maret; 2009.

[13] [13] Depkes RI. Pedoman Penyelenggaraan dan prosedur Rekam Medis Rumah Sakit di Indonesia. Jakarta: Departemen Kesehatan RI, 2008.

[14] [14] Jacobus R. "Hak Pasien Mendapatkan Informasi Resiko Pelayanan Medik". Jurnal Aplikasi Manajemen (JAM). 2014; 2(1):7-4.

[15] [15] Kemenkes RI. Standar Akreditasi Rumah Sakit Kerjasama Direktorat Jenderal Bina Upaya Kesehatan Kementerian Kesehatan Republik Indonesia Dengan Komisi Akreditasi Rumah Sakit (Kars). Jakarta : Kementerian Kesehatan RI; 2011.

[16] [16] Permenkes RI Nomor 512. Tentang Izin Praktik dan Pelaksanaan Praktik Kedokteran. Jakarta: Kementerian Kesehatan RI; 2007.

[17] [17] Natasia N, Loekqijana A, Kurniawati J. "Faktor yang Mempengaruhi Kepatuhan Pelaksanaan SOP Asuhan Keperawatan di ICU-ICCU RSUD Gambiran Kota Kediri”. Jurnal Kedokteran Brawijaya. 28(1):22-3 [2014].

[18] [18] Handayani L, Ma'ruf NA, Sopacua E. "Peran Tenaga Kesehatan Sebagai Pelaksana Pelayanan Pelayanan Kesehatan Puskesmas Buletin Sistem Penelitian Kesehatan. 2010”. 13(1):12-20.

[19] [19] Ginanjar L. "Komunikasi Terapeutik Dokter dan Paramedis Dengan Pasien di Rumah Sakit Umum PKU Muhammadiyah Karanganyar" skripsi. Surakarta: Universitas Sebelas Maret, 2013. 